\title{
Spatial dynamics, ecological thresholds and phase shifts: modelling grazer aggregation and gap formation in kelp beds
}

\author{
Jean-Sébastien Lauzon-Guay ${ }^{1, *}$, Robert E. Scheibling ${ }^{2}$ \\ ${ }^{1}$ Fisheries and Oceans Canada, Institut Maurice-Lamontagne, 850 route de la Mer, Mont-Joli, Québec G5H 3Z4, Canada \\ ${ }^{2}$ Biology Department, Dalhousie University, Halifax, Nova Scotia B3H 4J1, Canada
}

\begin{abstract}
On the Atlantic coast of Nova Scotia, transitions between alternative states of the subtidal ecosystem, kelp beds and sea urchin barrens, occur on a decadal scale. To explore the process of urchin aggregation within kelp beds that leads to the shift to barrens, we developed a coupled map lattice model to simulate the spatial dynamics of kelp and green sea urchin Strongylocentrotus droebachiensis abundance over time. Our simulations show that the following factors can cause sea urchins to form grazing aggregations that create gaps in a kelp bed: (1) random movement by $>60 \%$ of sea urchins residing in the bed, (2) moderate to high levels of spatial variability in sea urchin recruitment (30 to 90 [urchins $\left.\mathrm{m}^{-2}\right]^{2}$ ), (3) localized aggregation of sea urchins $\left(150\right.$ urchins $\mathrm{m}^{-2}$ ) amid a moderate to high background density of sea urchins within the kelp bed ( $>10$ urchins $\mathrm{m}^{-2}$ ), with or without a chemotactic response of sea urchins to kelp, and (4) removal of kelp from areas $>20 \mathrm{~m}^{2}$ (to simulate physical or biological disturbance, or harvesting). Gaps formed at random locations within the spatial domain and expanded and coalesced to form barrens in which sea urchins were randomly distributed. Sea urchins formed circular fronts around gaps in the kelp bed. The rate of advance of fronts (and increase in gap size) was linearly related to the density of sea urchins at the front. The duration of the transition to the barrens state decreased with increases in (1) the proportion $\left(P_{\mathrm{m}}\right)$ of sea urchins moving (from $>6 \mathrm{yr}$ for $P_{\mathrm{m}}=0.8$ to $<2 \mathrm{yr}$ for $P_{\mathrm{m}}=1$ ) and (2) the variance of sea urchin recruitment (from $>5 \mathrm{yr}$ for 30 [urchins $\left.\mathrm{m}^{-2}\right]^{2}$ to $<3$ yr for 90 [urchins $\left.\mathrm{m}^{-2}\right]^{2}$ ). Our findings support observations of gap formation within kelp beds that resulted in widespread destructive grazing on this coast in the late 1960s. Our model provides a predictive tool for the design of monitoring programs and field experiments to explore the underlying mechanisms of an ecosystem phase shift that has major ecological consequences.
\end{abstract}

KEY WORDS: Gap formation · Grazing · Kelp beds · Mathematical modelling • Phase shifts · Sea urchins $\cdot$ Spatial pattern $\cdot$ Thresholds $\cdot$ Strongylocentrotus droebachiensis

Resale or republication not permitted without written consent of the publishe

\section{INTRODUCTION}

The notion that ecosystems can exist in multiple stable states has long been recognized by ecologists. This concept rests on the premise that a state persists until mounting environmental change, or a perturbation of sufficient magnitude, drives the system beyond a threshold (breakpoint), causing a transition from one stable domain to another. Initial theoretical underpinnings (Holling 1973, May 1977) have become well grounded in empirical studies across a wide range of terrestrial, aquatic and marine ecosystems (reviewed by Folke et al. 2004, Scheffer et al. 2005, Schröder et al. 2005). In the marine realm, alternative states have been proposed for fouling communities (Sutherland 1974), kelp forests (Simenstad et al. 1978, Estes \& Duggins 1995), coral reefs (Hughes 1994, McManus \& Polsenberg 2004), rocky intertidal (Petraitis et al. 2009) and subtidal (Barkai \& McQuaid 1988) communities, soft sediments (van de Koppel et al. 2001) and pelagic and demersal fish assemblages (Steele 2004, Frank et al. 2005). Although there is considerable theoretical 
debate over the stability and alternativity or multiplicity of states (Peterson 1984, Sutherland 1990, Bertness et al. 2002, 2004, Petraitis \& Dudgeon 2004a,b, Schröder et al. 2005, Bruno et al. 2009, Mumby 2009), abrupt transitions between states often are viewed as catastrophic because they entail pronounced changes in ecosystem structure and function, and the loss of services that benefit humans (Folke et al. 2004, Scheffer et al. 2005). Therefore, in the face of global climatic change, identifying thresholds and understanding mechanisms that drive transitions between alternative ecosystem states (or phase shifts) has rapidly become a central issue in conservation ecology (Mumby et al. 2007, de Young et al. 2008, Andersen et al. 2009).

Analytical models of alternative states often have ignored spatial interactions, limiting their predictive power for spatially extensive, heterogeneous ecosystems (Rietkerk et al. 2004). More recently, however, mechanisms that explain spatial pattern formation have been identified (van de Koppel et al. 2008) and efforts have been made at linking patch-size distribution to community transitions (Kéfi et al. 2007). The alternative states of the kelp bed-sea urchin barrens ecosystem in the northwest Atlantic Ocean (Johnson \& Mann 1988) and in cold temperate regions globally (Dayton 1985, Steneck et al. 2002), is a prime example of the importance of spatial distribution patterns in governing transitions between states (Lauzon-Guay et al. 2009). Understanding scale-dependent feedback mechanisms and the potential for self-organized patchiness (Rietkerk et al. 2004) enables us to better resolve the threshold levels in kelp and sea urchin abundance at which phase shifts occur. On the Atlantic coast of Nova Scotia, Canada, the transition from barrens to kelp bed state occurs relatively rapidly (months to years) and over extensive areas as a result of mass mortality of green sea urchins Strongylocentrotus droebachiensis, the dominant grazers (Miller 1985, Scheibling 1986). In contrast, the reverse transition is more gradual and mediated by sea urchin behaviour and population structure (e.g. individual size, density and spatial distribution, Lauzon-Guay et al. 2009). Kelp beds are generally stable and may persist on decadal scales (Johnson \& Mann 1988). In areas where rocky substrata extend beyond the lower depth limit of kelp, deep-living sea urchins (unaffected by disease) form feeding aggregations (fronts) at the lower margin of regenerating kelp beds (Scheibling et al. 1999, Brady \& Scheibling 2005, Lauzon-Guay \& Scheibling 2007a). These fronts then propagate to shallow waters consuming all erect macroalgae and creating barrens in their wake. In areas where the lower limit of kelp beds is bounded by soft substrata, fronts do not form in deeper regions and the transition from kelp beds to barrens occurs within the beds rather than at their margins. Mann (1972) observed gaps with high densities of sea urchins within kelp beds. These gaps eventually expanded, resulting in a shift from kelp beds to barrens across a large section of coast (Breen \& Mann 1976b, Mann 1977).

Typically, high densities of consumers have drastic effects on the availability of resources. In some instances, these effects are simply the sum of individual contributions (Mumby et al. 2007). Alternatively, the effect of an aggregation can be greater than that expected from individual behaviours, as is the case when high densities of consumers lead to phenotypic (Anstey et al. 2009) or behavioural (Mann 1985) changes that affect resource availability. For example, crown-of-thorns sea stars Acanthaster planci are typically solitary at low density and have a negligible effect on coral reefs, but at high density they become gregarious and drastically transform the reef ecosystem by consuming live corals (Moran 1986). Similarly, sea urchins at low density within kelp beds do not aggressively feed on kelp but hide in crevices and feed on drift algae or detritus (Mann 1985). However, once their density exceeds a threshold level, sea urchins emerge from spatial refuges to collectively graze on attached seaweeds, leading to the destruction of kelp beds (Breen \& Mann 1976a,b, Scheibling et al. 1999).

In Nova Scotia, densities of sea urchins within kelp beds (Chapman 1981, Miller 1985, Scheibling et al. 1999) are usually much lower than the threshold density required for destructive grazing. Nonetheless, various factors can affect the spatial distribution of sea urchins, leading to localized, high-density aggregations (reviewed by Scheibling 1996). Here, we develop a spatially explicit mathematical model to evaluate factors that increase the likelihood of feeding aggregations that can create gaps in a kelp bed and precipitate a transition to the barrens state. More specifically, we use our model to address the following questions: (1) Can random movement of sea urchins result in aggregations that are capable of forming gaps within kelp beds? (2) Can spatial heterogeneity in sea urchin recruitment result in gap formation within kelp beds? (3) Is there a minimum background density of sea urchins required for gaps to propagate? (4) How does a chemotactic response of sea urchins to kelp affect the dynamics of gap formation and propagation? (5) What scale of disturbance (that creates a gap) is required for the propagation of gaps? (6) What is the relationship between the density of sea urchins at the margin of a gap and the rate of increase in gap size? We address these questions in a series of 'model experiments' that test the effects of specific parameter values on the formation and propagation of feeding aggregations that create gaps of barren substratum within our simulated kelp bed. 


\section{MATERIALS AND METHODS}

Model framework. We developed a coupled map lattice model (Solé \& Bascompte 2006) to simulate the spatial dynamics of kelp and sea urchin abundance over time. Coupled map lattice models consider space and time as discrete variables and state (as measured in terms of kelp biomass or sea urchin density) as a continuous variable. We used a $50 \times 50$ lattice of $1 \times 1 \mathrm{~m}$ cells, each with a neighbourhood of 4 cells. This cell size ensured that daily movement of sea urchins in our simulations $(1 \mathrm{~m})$ was consistent with field observations for Strongylocentrotus droebachiensis (range: 0.40 to $1.72 \mathrm{~m} \mathrm{~d}^{-1}$, Dumont et al. 2006). Boundary conditions were reflective; therefore, sea urchins could not leave the domain and, in the absence of mortality and recruitment, population size remained constant over time. Such a closed system is representative of kelp beds bounded by sand or other soft sediment unsuitable to sea urchins (Sivertsen \& Hopkins 1995).

Kelp dynamics. The dynamics of kelp within each cell follows the model of front formation of Strongylocentrotus droebachiensis developed by Lauzon-Guay et al. $(2008,2009)$. At each time step (1 d) seaweed biomass $\left(S_{t}\right)$ is calculated in each cell as:

$$
S_{t+1}=\max \left[S_{t} \mathrm{e}^{r\left(1-\frac{S_{t}}{K}\right)}-H U_{t}, 0\right]
$$

where $r$ and $K$ are the intrinsic growth rate and carrying capacity of kelp, respectively, $U_{t}$ is the local density of sea urchins (urchins $\mathrm{m}^{-2}$ ), and $H$ is a grazing function of sea urchins defined as:

$$
H=\left\{\begin{array}{ll}
g & \text { if } \frac{c U_{t}}{S_{t}}>T \\
0 & \text { if } \frac{c U_{t}}{S_{t}} \leq T
\end{array}\right\}
$$

where $c$ is the average mass of a sea urchin $(50 \mathrm{~g}), T$ is the feeding threshold ratio (0.5) of sea urchin to kelp biomass and $g$ is the individual grazing rate on kelp. A grazing function is necessary because field observations suggest that below a certain density sea urchins do not actively feed on erect macroalgae (Breen \& Mann 1976a,b, Scheibling et al. 1999, Lauzon-Guay \& Scheibling 2007a). Once seaweed biomass reached zero, it was reset to $50 \mathrm{~g}$ at the next time step to account for a constant supply of spores from adjoining cells. We used the same parameter estimates as those used in Lauzon-Guay et al. (2008, 2009), which resulted in a good agreement between model predictions and field observations.

Sea urchin movement. Sea urchins are mobile invertebrates and, in our simulations, movement occurred at each time step. The proportion of sea urchins moving from each cell was dependent on the biomass of sea- weed within the cell. Sea urchins could only move from their cell into the 4 neighbouring cells. Sea urchins exhibit different foraging behaviours in kelp beds and barrens: sea urchins in a kelp bed generally are sedentary, feeding mainly on drift kelp, while those in barrens move in search of food (Mann 1985). For simplicity, we considered cells with $<100 \mathrm{~g}$ of seaweed as being in the barrens state, and cells with $>100 \mathrm{~g}$ of seaweed as being in the kelp bed state. This dichotomy between states is realistic, as the switch from kelp beds to barrens usually occurs over a very narrow boundary (1 to $2 \mathrm{~m}$, Lauzon-Guay \& Scheibling 2007a) and sea urchins generally do not leave the boundary until most of the kelp biomass has been consumed. In barrens cells, all sea urchins moved at each time step, while in kelp bed cells, no sea urchins moved or only a proportion $\left(P_{\mathrm{m}}\right)$ of the population moved. In simulations without chemotaxis, the proportion of sea urchins moving from each cell was randomly redistributed to its 4 neighbouring cells. When chemotaxis was included in the model, the proportion of sea urchins moving to a cell $j\left(p_{j}\right)$ was proportional to the biomass of seaweed $\left(S_{i}\right)$ in the 4 neighbouring cells $(i)$, such that:

$$
p_{j}=\frac{S_{j}}{\sum_{i=1}^{4} S_{i}}
$$

If none of the neighbouring cells contained seaweed, sea urchins redistributed randomly among neighbouring cells.

Urchin population growth. Unless otherwise specified, we set initial conditions of seaweed biomass at carrying capacity in all cells $\left(4000 \mathrm{~g} \mathrm{~m}^{-2}\right.$, Mohn \& Miller 1987, Lauzon-Guay et al. 2008) and sea urchin density at the average reported for this species in kelp beds (14 urchins $\mathrm{m}^{-2}$, Meidel \& Scheibling 2001). Only adult sea urchins (individual mass $=50 \mathrm{~g}$ ) are considered in our model of front formation, and all references to sea urchin density are for adults. When simulations were continued for more than $1 \mathrm{yr}$, we included sea urchin recruitment and survival. Precise estimates of survival in barrens and kelp beds are not available; therefore, we used a constant survival rate independent of the state of each cell $(84 \%$, Russell et al. 1998, Chen \& Hunter 2003) to parameterize our model. We used different values of recruitment for cells in the barrens versus kelp bed state (44 and 17 recruits $\mathrm{m}^{-2}$, respectively, Balch \& Scheibling 2000). We also assumed that recruits would spend 2 yr as juveniles before becoming adults foraging in the open (Scheibling \& Hamm 1991). Survival rate of juveniles (62\%, Raymond \& Scheibling 1987) is generally lower than that of adults; therefore, we added only $38 \%\left(0.62^{2}\right)$ of the recruiting sea urchins to each cell every 365 time steps to account for the mortality that would have 
occurred during their juvenile stage. Mean recruitment was constant for each state from one year to the next, but varied spatially. We randomly selected the level of recruitment for each cell of the model each year from a log-normal distribution (Evans et al. 2000) for different variance levels. Recruits entered into our model of front formation only once they became adults.

Simulations. We conducted a series of model experiments to test the effects of parameter values on the formation of feeding aggregations and gaps in our simulated kelp bed, as well as on the propagation of these gaps and shift to the barrens state. We considered that a gap had formed within a kelp bed when seaweed biomass within a cell fell below $100 \mathrm{~g}$ (the lower threshold for the barrens state). Unless otherwise stated, we ran 100 replicate runs of the model for each set of parameter values in an experiment. Each time step in a simulation was $1 \mathrm{~d}$. Separate experiments are described as follows:

Expt 1. To test whether random movement of sea urchins could create gaps within kelp beds we ran simulations with different proportions of the population moving $\left(P_{\mathrm{m}}\right)$. For each level of $P_{\mathrm{m}}$ (ranging from 0.6 to 1.0), we calculated the probability of a gap forming at each time step over 1 yr. For each level of $P_{\mathrm{m}}$ that resulted in a gap forming $\left(P_{\mathrm{m}} \geq 0.8\right)$ within the first year, we ran additional simulations $(\mathrm{n}=100)$ to track the transition from kelp bed to barrens as the gaps grew within the model domain. For each time step, we calculated the percentage of the barren cells for up to $6 \mathrm{yr}$.

Expt 2. To test whether spatial heterogeneity in recruitment results in gap formation within kelp beds we ran simulations with the same mean values of recruitment, but with different levels of variance in recruitment $\left.\left(10,30,50,70,90 \text { [urchins } \mathrm{m}^{-2}\right]^{2}\right)$ between cells. We calculated the cumulative probability of gap formation over $6 \mathrm{yr}$, and tracked the transition from kelp bed to barrens as in Expt 1.

Expt 3. To test the effect of sea urchin density in a kelp bed on the propagation of a gap formed by a localized aggregation of sea urchins, we added 150 sea urchins to the center cell of our lattice (density $=7.5 \mathrm{~kg}$ $\mathrm{m}^{-2}$ ) to exceed the threshold of sea urchin:kelp biomass (0.5) for destructive grazing, and ran simulations with different levels of sea urchin density $(5,10,11,14$ urchins $\mathrm{m}^{-2}$ ) in all other cells. For each level of sea urchin density, we followed the change in gap size over 2.75 yr.

Expt 4. To test the effect of chemotaxis on gap dynamics, we repeated Expt 3 with 150 sea urchins in the central cell and 14 urchins $\mathrm{m}^{-2}$ in other cells (which resulted in the formation of a gap that expanded over time) and compared simulations with sea urchins moving randomly over 4 yr with those in which urchins exhibit directed movement toward kelp via chemotaxis.
Expt 5. To test whether the scale of disturbance events (removal of kelp) affected the propagation of gaps created in a kelp bed we ran simulations over $1 \mathrm{yr}$ with gaps of different initial size (ranging from 1 to $81 \mathrm{~m}^{2}$ ) that were cleared at the center of the bed and followed the change in gap size over 1 yr.

Expt 6. To examine the rate of increase in gap size and sea urchin density at the front surrounding a gap, we repeated Expt 5 with an initial gap size of $36 \mathrm{~m}^{2}$ and ran simulations over $2.5 \mathrm{yr}$.

In all simulations sea urchin population size was held constant (i.e. we did not include recruitment or mortality in the model) except in Expt 2, which was aimed at testing the effect of spatial variability in recruitment. Sea urchins did not move within kelp beds $\left(P_{\mathrm{m}}=0\right)$ in all simulations, except in Expt 1, which was aimed at testing the effect of the proportion moving within kelp beds.
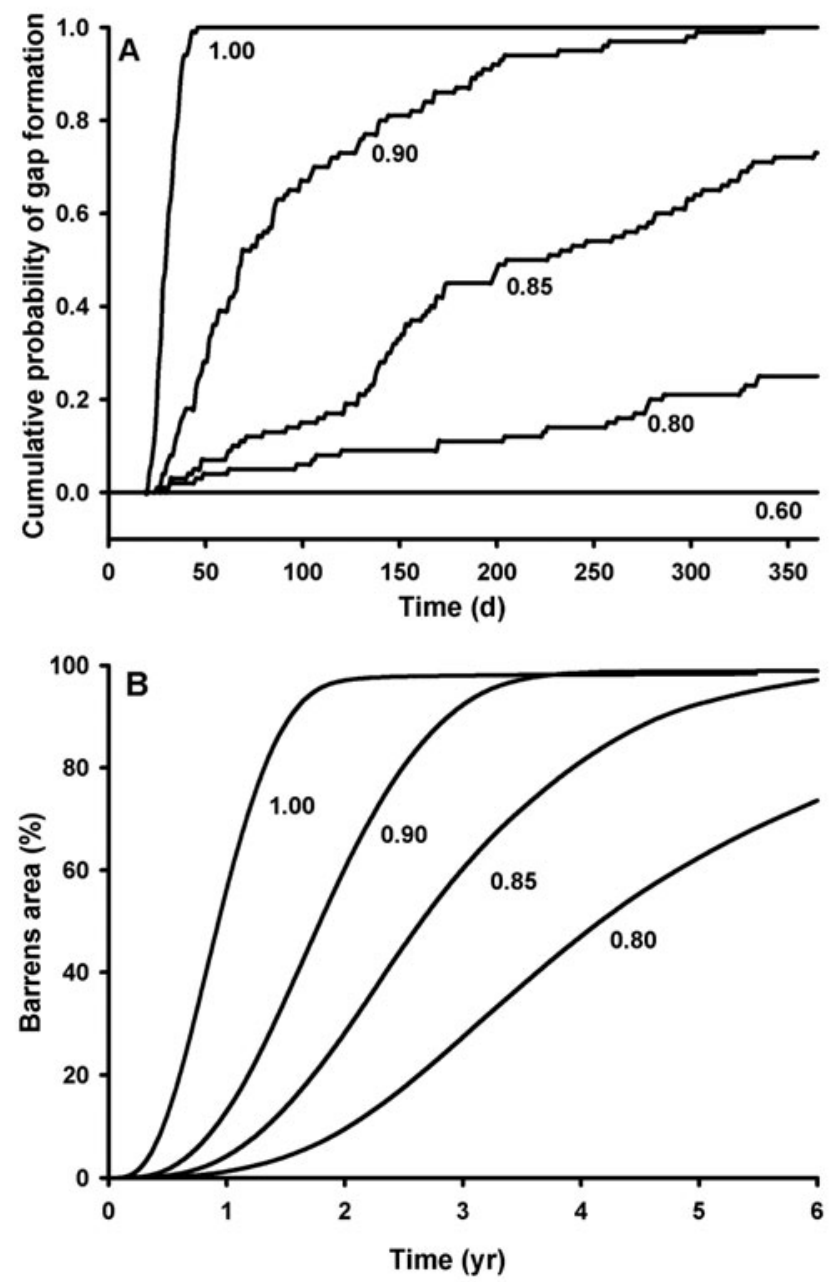

Fig 1. Expt 1. Effect, over time, of the proportion of sea urchins moving randomly within a kelp bed $\left(P_{\mathrm{m}}\right)$ on $(\mathrm{A})$ the probability of gap formation within the bed and (B) the percentage of the spatial domain in a barrens state. Numbers below lines are $P_{\mathrm{m}}$ used in simulations 
Elasticity analysis. We calculated the elasticity of the proportion of the landscape in a barren state after $1 \mathrm{yr}$ to changes in parameter values $\left(T, g, P_{\mathrm{m}}, K\right.$ and $\left.r\right)$ and in the cut-off biomass of kelp (set at $100 \mathrm{~g}$ ) that designates a cell as being either in the kelp bed or barrens state. Initial conditions were those of Expt 1 with a proportion of sea urchins moving $\left(P_{\mathrm{m}}\right)$ of 0.85 . We increased each parameter by $1 \%$ separately, ran 200 simulations and calculated the proportional change in the model output after $1 \mathrm{yr}$.

\section{RESULTS}

In Expt 1, gaps formed within 1 yr when $>60 \%$ of sea urchins were allowed to move randomly within kelp beds (Fig. 1A). When all sea urchins were allowed to move, gaps formed within $90 \mathrm{~d}$ in all simulations. Gaps formed at random locations within the spatial domain and, once formed, expanded and coalesced to form barrens in which sea urchins were randomly distributed (Fig. 2A). The transition to the barrens state was more rapid when high proportions of sea urchins were allowed to move within kelp beds (Fig. 1B). On average, the transition to a barrens state was complete in $<2 \mathrm{yr}$ when $P_{\mathrm{m}}=1.0$, while it took $>6 \mathrm{yr}$ when $P_{\mathrm{m}}=0.8$ (Fig. 1B).

In Expt 2, spatial variability in recruitment had a large effect on the probability of gap formation (Fig. 3A). Gaps formed within $1 \mathrm{yr}$ in all simulations when variance in recruitment was $>70$ (urchins $\left.\mathrm{m}^{-2}\right)^{2}$. The same probability was attained after 2 and $3 \mathrm{yr}$ with variances of 50 and 30 (urchins $\mathrm{m}^{-2}$ ) ${ }^{2}$, respectively. After $6 \mathrm{yr}$, gaps formed in $60 \%$ of simulations with a variance in recruitment of 10 (urchins $\left.\mathrm{m}^{-2}\right)^{2}$ (Fig. 3A). Increasing the variance in recruitment of sea urchins in the kelp bed also accelerated the transition to the barrens state (Fig. 3B). The transition was complete within 3 yr with a variance of 90 (urchins $\left.\mathrm{m}^{-2}\right)^{2}$, while barrens cover was only $10 \%$ after $6 \mathrm{yr}$ with a variance of 10 (urchins $\left.\mathrm{m}^{-2}\right)^{2}$ (Fig. 3B). The pattern of patch dynamics resulting from variance in recruitment (Fig. 2B) was similar to that resulting from random movement of sea urchins within kelp beds (Fig. 2A),
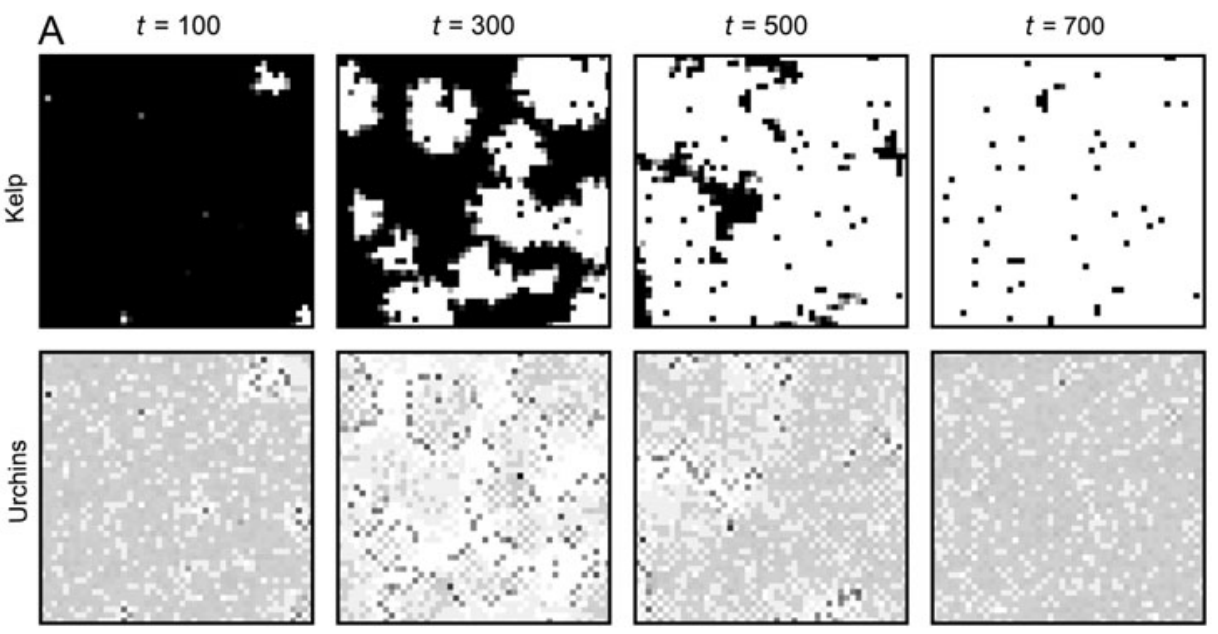

Fig. 2. Expts 1 and 2 (Panels A and $B$, respectively). Schematic representations of (A) a simulation run over $700 \mathrm{~d}$ with a $100 \%$ probability of sea urchins moving within the kelp bed $\left(P_{\mathrm{m}}=1\right)$ and without recruitment and (B) a simulation run over $1100 \mathrm{~d}$ without sea urchin movement $\left(P_{\mathrm{m}}=0\right)$ and a variance in recruitment of 90 (urchins $\left.\mathrm{m}^{-2}\right)^{2}$. Darker cells represent higher kelp biomass (top rows) and higher sea urchin density (bottom rows); white cells have a value of 0
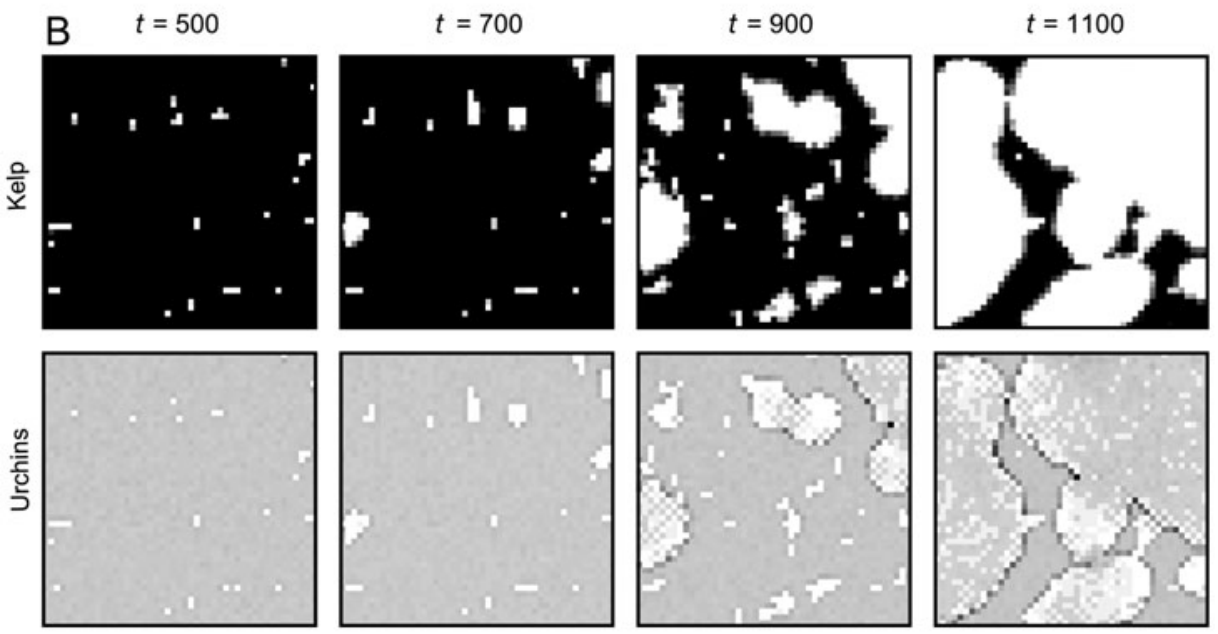

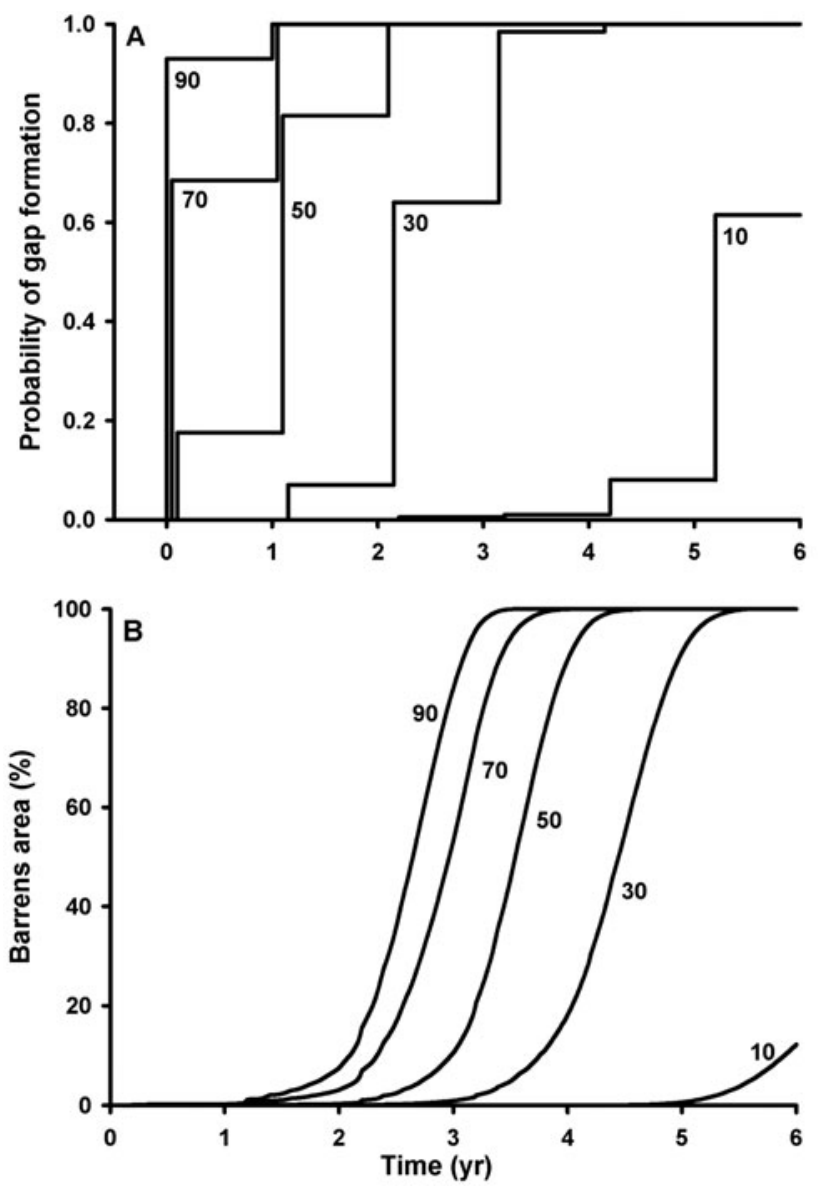

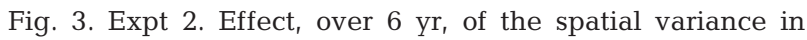
recruitment on (A) the time to gap formation within a kelp bed and (B) the percentage of the spatial domain in a barrens state. Numbers below lines are the variance in recruitment ([urchins $\left.\mathrm{m}^{-2}\right]^{2}$ ) in simulations. Recruitment in each cell of the model was selected randomly from a log-normal distribution with a mean of 44 and 17 recruits $\mathrm{m}^{-2}$ for cells in barrens and kelp bed states

although small isolated patches of kelp survived temporarily within large clearings.

In Expt 3, the density of sea urchins in the kelp bed had an effect on the propagation of the front formed by a localized aggregation of sea urchins (150 urchins $\mathrm{m}^{-2}$ ) at the center of the spatial domain (Fig. 4). At densities $<10$ urchins $\mathrm{m}^{-2}$ throughout the rest of the kelp bed, a gap formed but eventually stopped expanding and kelp recolonized the gap. At densities $>10$ urchins $\mathrm{m}^{-2}$ gap size increased at an accelerating rate.

In Expt 4, gaps formed in all simulations (with a localized aggregation of sea urchins at the center of the domain and 14 urchins $\mathrm{m}^{-2}$ throughout the rest of the kelp bed) whether or not chemotaxis (directed movement) was included in the model (Fig. 5). A circular front developed that radiated outwards from the initial release point of sea urchins. The front was com-

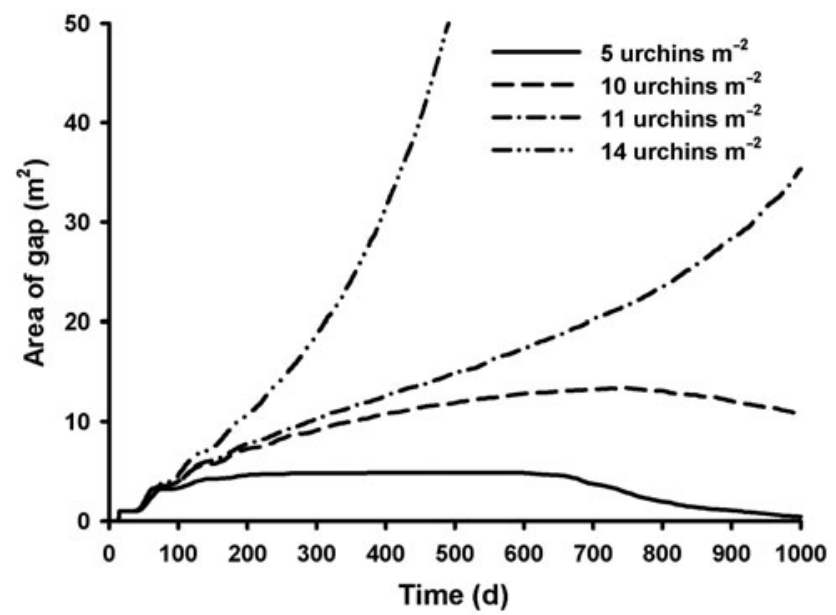

Fig. 4. Expt 3. Effect, over $1000 \mathrm{~d}$, of sea urchin density in a kelp bed on the increase in area of a gap formed by a local aggregation of urchins (150 urchins $\mathrm{m}^{-2}$ ) at the center of the domain

posed of more individuals, and advanced more rapidly, in simulations with chemotaxis than in simulations with random movement of sea urchins. Without chemotaxis, a small number of sea urchins remained within the gap as the front advanced and prevented regrowth of kelp within the gap. With chemotaxis, sea urchins were almost absent from the clearing and a small amount of kelp started to grow in the centre of the clearing after 1 yr. The emergent kelp bed grew in size and biomass for $3 \mathrm{yr}$. Once sea urchin fronts reached the boundary of our spatial domain sea urchins spread within the clearing and the front dissipated. A small front later developed around the newly formed kelp bed in the center of the clearing (after $3.5 \mathrm{yr}$, data not shown) and consumed all kelp by Year 4 (Fig. 5).

In Expt 5, kelp beds were resilient to small-scale disturbances that removed kelp at the center of the spatial domain: clearings $<20 \mathrm{~m}^{2}$ did not increase in size after $1 \mathrm{yr}$, while larger clearings resulted in gaps that grew in proportion to the initial clearing size (Fig. 6). In Expt 6 , with an initial clearing of $36 \mathrm{~m}^{2}$, sea urchin density at the front surrounding the gap increased over $2.5 \mathrm{yr}$ (Fig. 7A), resulting in an increase in the rate of advance of the front, which was measured as the change in the square root of the gap area (Fig. 7B). There was a strong linear relationship $\left(\mathrm{r}^{2}=0.97, \mathrm{p}<\right.$ $0.001)$ between rate of front advance $\left(A, \mathrm{~m} \mathrm{mo}^{-1}\right)$ and sea urchin density $\left(U\right.$, urchins $\left.\mathrm{m}^{-2}\right)$ at the front: $A=$ $-2.051+0.066 U$ (Fig. 7C).

Elasticity analysis indicates that model estimates of the proportion of the landscape in a barren state after $1 \mathrm{yr}$ is particularly sensitive to small increases in the proportion of sea urchins moving $(35.9 \%$ increase) or the feeding threshold ( $27.7 \%$ decrease). Increasing sea 

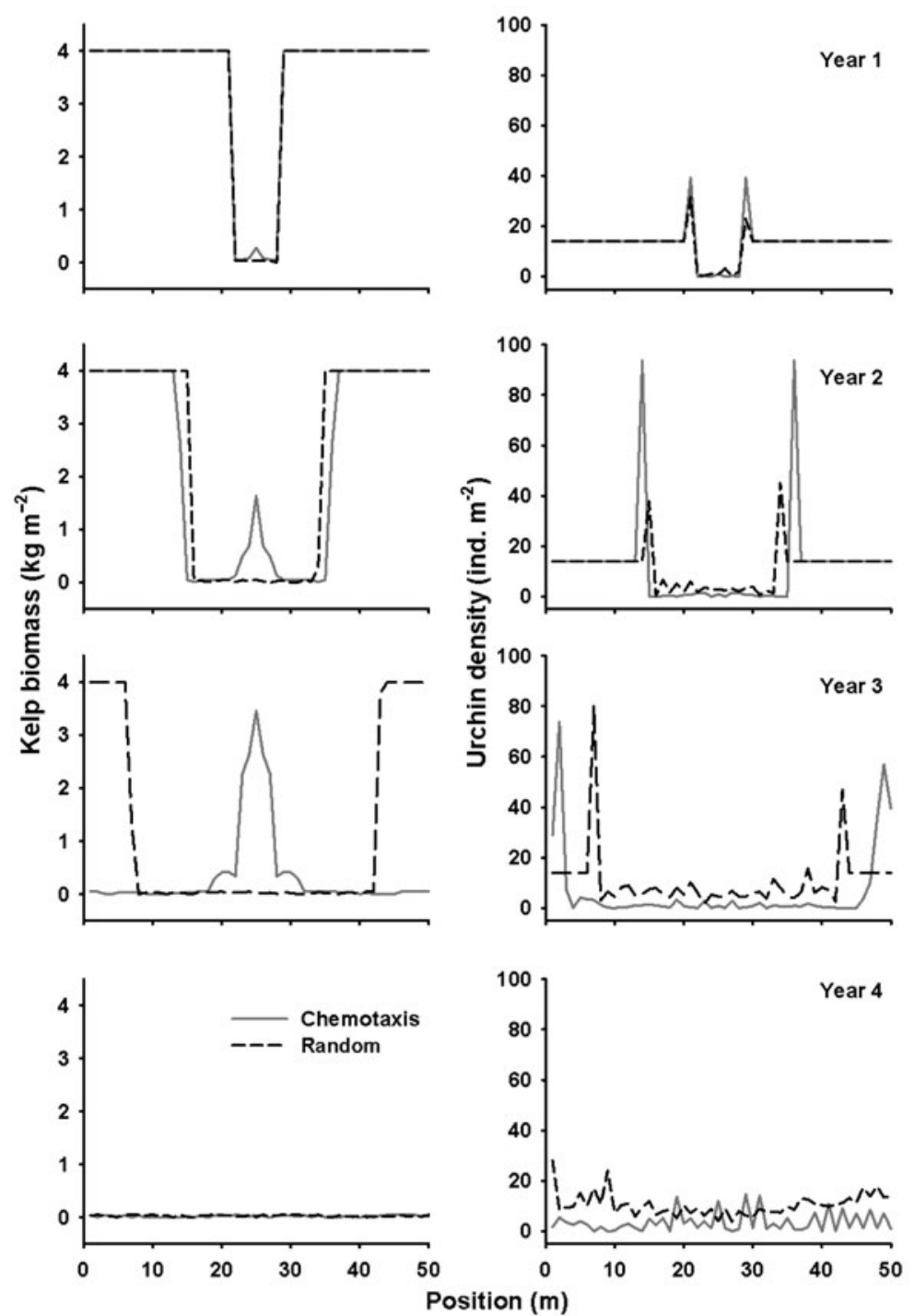

Fig. 5. Expt 4. Propagation of a feeding front for sea urchins exhibiting random movement or directed movement (chemotaxis) at a gap formed by a local aggregation of urchins (150 urchins $\mathrm{m}^{-2}$ ) at the center of the domain $(x=25, y=25)$, and an initial sea urchin density of 14 urchins $\mathrm{m}^{-2}$ in all other cells. Kelp biomass (left column) and sea urchin density (right column) over $4 \mathrm{yr}$ are shown along a transect in the center of the spatial domain $(y=25)$

debated (Wharton \& Mann 1981, Elner \& Vadas 1990, Scheibling 1996), and only recently has a mechanistic understanding of front formation come to light (Lauzon-Guay et al. 2008). Several studies have described the onshore advance of grazing fronts, driven by migration of sea urchins from greater depths (Scheibling et al. 1999, Brady \& Scheibling 2005, LauzonGuay \& Scheibling 2007a). Deep-dwelling sea urchins (below 20 to $25 \mathrm{~m}$ ) appear to have a thermal refuge from a disease that periodically decimates populations in shallow water (Scheibling 1984, Scheibling \& Stephenson 1984, Scheibling et al. 1999). A mathematical model of the formation and advance of grazing fronts, and consequent phase shift from kelp beds to urchin barrens, predicts sea urchin density at fronts and the rate of transition between states with reasonable accuracy (Lauzon-Guay et al. 2008, 2009). However, this previous model is predicated on the assumption that refuge populations of sea urchins, which serve as a source of migrants and larval recruits, exist in deeper waters. Surveys of steeply sloping headlands reveal extensive populations of $S$. droebachiensis on deep rocky substrata along this urchin grazing rates resulted in an increase in the proportion of barrens by $8.1 \%$, while increases in kelp carrying capacity, growth rate and the cut-off kelp biomass resulted in decreases of $9.5,6.9$ and $3.3 \%$, respectively.

\section{DISCUSSION}

\section{Effects of sea urchin behaviour, density and recruitment variation on gap formation}

On the Atlantic coast of Nova Scotia, the occurrence of dense aggregations of Strongylocentrotus droebachiensis in the rocky subtidal zone, resulting in destructive grazing of kelp beds, has been well documented (reviewed by Scheibling \& Hatcher 2006). Causative factors underlying increases of sea urchin abundance that presage these events have been hotly

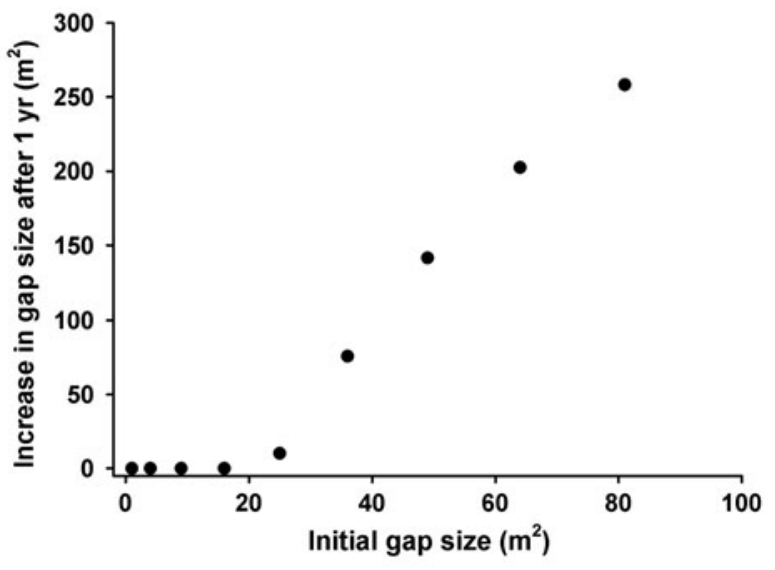

Fig. 6. Expt 5. Effect of the spatial scale of a disturbance (removal of kelp) that generates a gap on the increase in gap size within a kelp bed after 1 yr. Gaps of varying size (ranging from 1 to $81 \mathrm{~m}^{2}$ ) were created at the center of the kelp bed at the beginning of each simulation run 

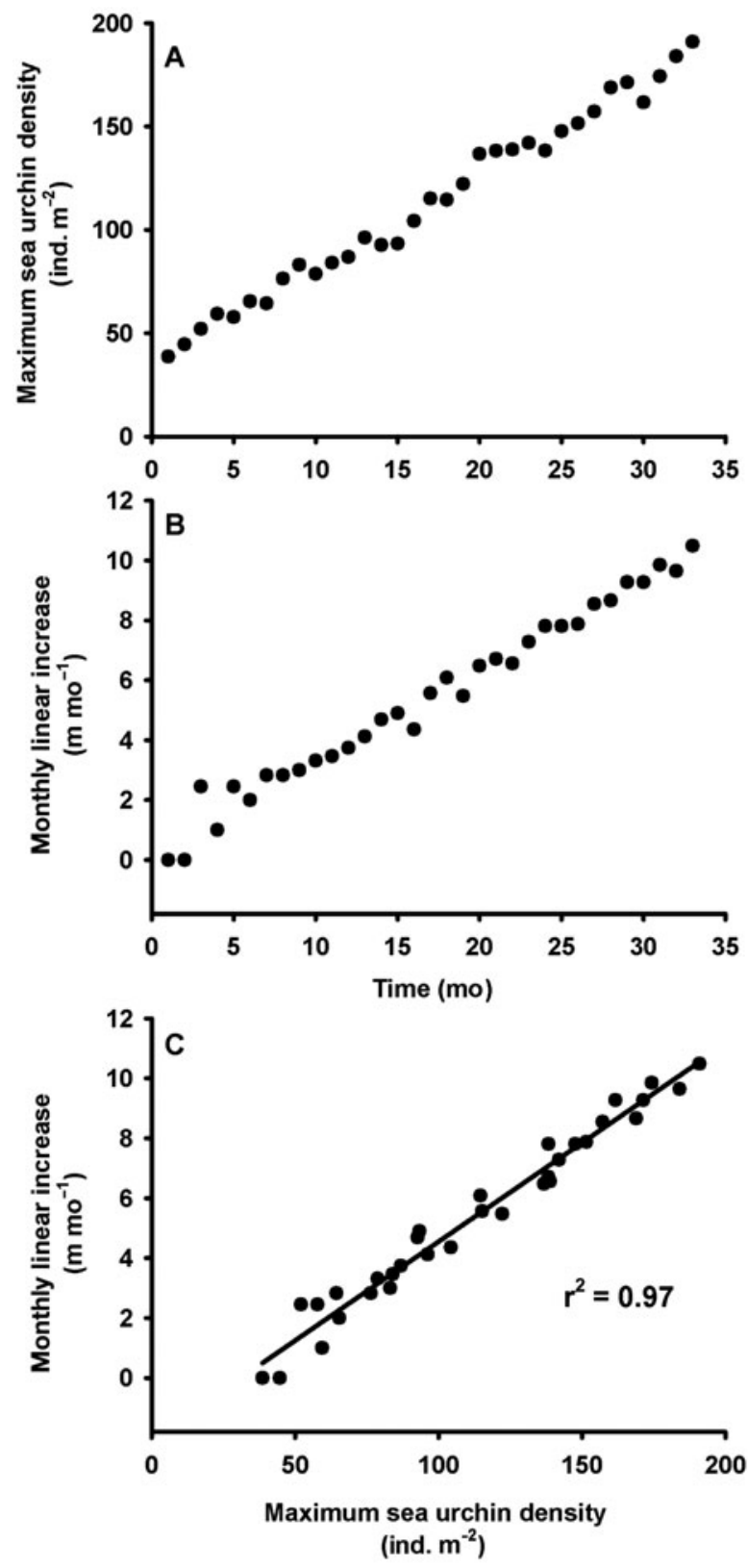

Fig. 7. Expt 6. Expansion of a gap $\left(36 \mathrm{~m}^{2}\right)$, created within a kelp bed at the center of the domain, over $1000 \mathrm{~d}$. (A) Increase in the maximum sea urchin density at the front surrounding the gap over time. (B) Increase in the rate of advance of the front over time as measured by the change in the square root of the gap area. (C) Relationship between the increase in front advance and maximum sea urchin density

coast (Brady \& Scheibling 2005, R. E. Scheibling unpubl. data).

The above scenario does not apply to large semiprotected bays where the rock substratum typically grades to sand (an unsuitable sea urchin habitat) above 25 m (Mann 1972). In these areas sea urchin populations can be completely eliminated by severe outbreaks of disease and kelp beds become re-established within 2 yr (Miller 1985, Scheibling 1986). Destructive grazing of Nova Scotian kelp beds by Strongylocentrotus droebachiensis was first documented in this type of habitat. Breen \& Mann (1976a,b) hypothesised that the biomass of sea urchins in kelp beds in St. Margarets Bay, Nova Scotia, had increased to the point where urchins began grazing 'holes' in the kelp canopy at several locations. These gaps progressively expanded and coalesced, such that $70 \%$ of the kelp bed along $15 \mathrm{~km}$ of shoreline was destroyed within 6 yr (Mann 1977).

To explore how sea urchin aggregations and gaps in the kelp canopy may form within kelp beds, we embedded our model of front formation (Lauzon-Guay et al. 2008) in a coupled map lattice framework. An integral component of this model is the feeding threshold, the ratio of urchin:kelp biomass at which sea urchins exhibit a behavioural shift from feeding on drift algae to cooperatively grazing by climbing up and weighing down kelp blades. Kelp beds will regress only once the ratio of sea urchin to kelp biomass at the boundary exceeds the threshold value. Our understanding of this switch in foraging behaviour is based mainly on field observations that destructive grazing of kelp beds occurs once sea urchin biomass exceeds $\sim 2 \mathrm{~kg} \mathrm{~m}^{-2}$ (Breen \& Mann 1976a, Scheibling et al. 1999, Lauzon-Guay \& Scheibling 2007a); no experimental tests have been conducted to rigorously evaluate this threshold, but the high sensitivity of our model output to changes in the threshold value suggests that it can affect the state of the system. Environmental factors, such as wave action, temperature and the availability of spatial refuges and drift algal material, can influence the propensity of sea urchins to forage gregariously (Scheibling \& Hamm 1991, Konar \& Estes 2003, Lauzon-Guay \& Scheibling 2007b), as can the sizestructure and density of kelp and sea urchin populations (Scheibling et al. 1999, Lauzon-Guay et al. 2008). The complex balance between consumers and a resource is a common feature controlling boundaries in other marine systems (Silliman et al. 2005, Robles et al. 2009).

Our simulations (Expt 1) indicate that random movement of sea urchins within a kelp bed is sufficient for destructive grazing aggregations to form, and that even small changes in the proportion of urchins moving can have large effects on the state of the system. The probability of an aggregation forming increased with the proportion of sea urchins moving above a threshold proportion of $60 \%$. The few studies that have examined movement of Strongylocentrotus droebachiensis within kelp beds suggest that these sea urchins are mainly sedentary (Foreman 1977, Dumont et al. 2006). Therefore, it seems unlikely that $60 \%$ of 
the urchins would move a distance of $1 \mathrm{~m}$ in a day while foraging. It is possible, however, that external factors, such as the presence of predators, could locally increase the movement of sea urchins, which in turn could lead to the formation of feeding aggregations (Bernstein et al. 1983, Vadas et al. 1986).

Over longer time scales (years to decades), the stochastic nature of larval recruitment (Siegel et al. 2008) also could result in sufficient spatial heterogeneity in sea urchin density for aggregations to form locally without requiring urchin movement. Variance in recruitment between $1 \mathrm{~m}^{2}$ quadrats can be as high as $\sim 45$ (recruits $\left.\mathrm{m}^{-2}\right)^{2}$ (estimated from Fig. 6 in Balch \& Scheibling 2000). Our simulations (Expt 2) indicate that destructive grazing aggregations could form in 1 or 2 annual recruitment events. This relatively short time scale suggests that spatial (or temporal) variability in recruitment alone could provide the necessary mechanism for formation of gaps within kelp beds. Spatial heterogeneity could increase spatial variance in recruitment by creating 'hot-spots' where recruitment is consistently higher due to larval retention, or because a more suitable microhabitat increases rates of settlement or post-settlement survival (Scheibling \& Robinson 2008).

Our simulations (Expts 1 and 2) provide estimates of the rate of transition from kelp bed to barrens at varying levels of movement or variance in recruitment. When all sea urchins moved within the kelp bed, the minimum transition time was $1.5 \mathrm{yr}$ compared with $>6 \mathrm{yr}$ when $<85 \%$ of sea urchins moved. If spatial variation in recruitment is the mechanism for gap formation, then our model predicts a minimum transition time of $3 \mathrm{yr}$, when the variance in recruitment is 90 (urchins $\left.\mathrm{m}^{-2}\right)^{2}$, but well over $6 \mathrm{yr}$ when variance is 10 (urchins $\left.\mathrm{m}^{-2}\right)^{2}$. These model estimates of the rate of transition from kelp bed to barrens are within the range observed for fronts moving onshore from deep waters (Scheibling et al. 1999, Brady \& Scheibling 2005, Lauzon-Guay \& Scheibling 2007a). As mentioned above, the only documented case of a transition occurring through sea urchin aggregation within a kelp bed (St. Margarets Bay) suggests a span of $\sim 6 \mathrm{yr}$ between the occurrence of gaps (tens of metres in diameter, Mann 1972) and the shift to sea urchin barrens (Breen \& Mann 1976b). Although the initial formation of gaps in the kelp bed or the point at which the transition to barrens was complete are not precisely known in this case, the time course of the observed transition is within the range predicted by our model.

The density of adult sea urchins in kelp beds directly affects the number accumulating at the moving front as a gap increases in size. Based on field surveys, sea urchin density within kelp beds can be highly variable, ranging from 0 to 239 urchins $\mathrm{m}^{-2}$ (Meidel \& Scheibling
2001), although high densities typically reflect recruitment pulses that contribute little to overall sea urchin biomass because of the small size of juveniles. Our simulations (Expt 3) suggest that a background density of $>10$ adult urchins $\mathrm{m}^{-2}$ is needed for a sea urchin front, formed by a localized aggregation of urchins within the kelp bed, to advance over time. When the density of adult sea urchins in the surrounding kelp bed exceeds this threshold, our model predicts that gaps will expand in area over time, even if there is no movement of urchins within the surrounding kelp bed.

In a previous application of our grazing model we suggested that sea urchins could form fronts without a chemotactic response to kelp (Lauzon-Guay et al. 2008), which is in contrast to littorinid snails that appear to use chemotaxis to form grazing fronts in salt marshes (Silliman et al. 2005). Although chemotaxis may be beneficial at the individual level in optimizing foraging efficiency, our simulations (Expt 4) show that chemotaxis, while increasing the rate of front advance, also increases the resilience of the system by enabling kelp beds to reform after passage of a sea urchin front. Barrens can be stable at large spatial and temporal scales (Mann 1977, Wharton \& Mann 1981), which supports the notion that chemotaxis is not involved in the formation of sea urchin fronts (Lauzon-Guay et al. 2008). Rather, random foraging movements of sea urchins and a limited ability to detect distant food sources, may be responsible, in part, for the long-term persistence of barrens. If urchins were more effective at detecting kelp by chemoreception, kelp beds may be able to reestablish in barrens without the mass mortality of sea urchins.

\section{Role of disturbance on gap formation and phase shifts}

Apart from factors affecting sea urchin populations, disturbance events that result in a loss of kelp biomass (e.g. kelp harvesting, strong wave forces that fragment or dislodge thalli) also can influence kelp bed stability (Steneck et al. 2002, Konar \& Estes 2003). A reduction in kelp biomass would have the same effect as an increase in sea urchin density on the feeding threshold (urchin:kelp biomass) for destructive grazing. Our simulations (Expt 5) show that kelp beds are resilient to small-scale disturbances that create gaps $<20 \mathrm{~m}^{2}$, which do not expand after 1 yr. Larger disturbances, however, can produce gaps that grow in proportion to the initial gap size. Sea urchins within disturbed areas are likely to start moving in search of food once the kelp canopy is removed (Lauzon-Guay et al. 2006). As the size of the disturbed area increases, a greater number of sea urchins become active and, through random 
movement, eventually encounter the edge of the clearing, where they accumulate. If clearings are small, urchins simply remain at the edges and kelp eventually recolonises the disturbed area. However, if the clearings are sufficiently large, sea urchin density at the kelp edge reaches the threshold value and grazing aggregations form.

Whether clearings continue to grow over time also depends on sea urchin density within surrounding kelp beds. Unlike fronts forming at the lower limit of kelp beds, fronts within kelp beds are circular features that increase in length over time as the circumference of the clearing increases. Therefore, without a constant influx of sea urchins to the front, the density of urchins per linear metre of front will inevitably decrease as the front advances. If an insufficient number of sea urchins are being recruited to the front urchin density may fall below the threshold value and the front will cease advancing. When density exceeds the threshold, our simulations (Expt 6) show that gap size (measured as the square root of the clearing area) increases linearly with the density of sea urchins at the front. This linear relationship between the rate of advance of a sea urchin front (resulting in the increase in gap size) and the density of urchins within the front is consistent with field observations (Breen \& Mann 1976a, Scheibling et al. 1999, Lauzon-Guay \& Scheibling 2007a) and previous model predictions (Lauzon-Guay et al. 2008, 2009).

The invasion of an epiphytic bryozoan, Membranipora membranacea, has resulted in mass defoliation of kelp beds and reductions in kelp cover of over $70 \%$ (Scheibling et al. 1999, Saunders \& Metaxas 2008, Scheibling \& Gagnon 2009). These disturbance events could greatly increase the probability of gap formation in affected beds with sufficient densities of sea urchins (Scheibling et al. 1999). However, large-scale defoliation of kelp beds by this bryozoan also facilitates the establishment of an invasive green alga, Codium fragile ssp. fragile (formerly ssp. tomentosoides), which can displace kelp and become the dominant canopy-forming seaweed (Chapman et al. 2002, Levin et al. 2002, Scheibling \& Gagnon 2006). The formation of dense Codium meadows in some areas, which exceed the biomass of former kelp beds (Chapman et al. 2002), is likely to affect the potential for gap formation by destructive sea urchin grazing. Although Strongylocentrotus droebachiensis consumes $C$. fragile when other algal foods are unavailable (Scheibling \& Anthony 2001, Sumi \& Scheibling 2005), a chemical feeding deterrent (Lyons et al. 2007) renders the invasive alga unpalatable to sea urchins, and it is generally avoided in the presence of other seaweeds (Lyons \& Scheibling 2007, 2008). In the only published account of a sea urchin front encountering a mixed algal stand that included $C$. fragile, the urchins appeared to bypass C. fragile and another chemically defended seaweed before succumbing to an outbreak of disease (Lyons \& Scheibling 2008). Therefore, the question of whether feeding aggregations of sea urchins can form within or at the margins of Codium meadows remains unresolved, as does the value of the feeding threshold that triggers such aggregations.

\section{Conclusions and prospects for further research}

Our simulations show that destructive grazing aggregations can form within kelp beds in response to various factors that influence the foraging behaviour, abundance and spatial distribution of sea urchins, resulting in a transition to urchin barrens. We also show that disturbances that remove kelp on scales of tens of square metres, also can precipitate destructive grazing and gap formation in kelp beds by providing conditions that facilitate the formation of sea urchin fronts. Predictions based on our model are consistent with empirical observations that large-scale disturbance (tens to hundreds of square metres) are required to destabilise kelp beds on the Atlantic coast of Nova Scotia (Johnson \& Mann 1988). However, even small human-induced changes that have little apparent effect on ecosystem state can alter resilience of an existing state and, hence, the likelihood of a phase shift (Scheffer et al. 2001). Therefore, while human activity (e.g. overexploitation of predatory fishes, kelp harvesting) may not appear to directly affect kelp beds, such perturbations may nonetheless facilitate the shift to sea urchin barrens. Although predicting the occurrence of a phase shift in this system will be difficult because of stochastic processes, monitoring may provide the best predictive tool. Rietkerk et al. (2004) hypothesised that catastrophic shifts in ecosystems can be predicted by self-organised patchiness. For the rocky subtidal ecosystem of the Atlantic coast of Nova Scotia, the presence of gaps and sea urchin aggregations within kelp beds is probably an early warning sign that the system is in its transitional stage. The presence of spatial patterns, indicating the imminent transition between states, has also been suggested for arid ecosystems, where patch-size distribution can serve as a warning sign of desertification (Kéfi et al. 2007).

Mathematical models, such as ours, can be used to inform the design of monitoring programs and field experiments to test predictions about the pattern and process of phase shifts. Our approach could be used in other systems where consumers play a role in controlling the trajectory of the ecosystem. This is likely to be the case for grasslands (Pech et al. 1992), coral reefs (Lewis 1986), rocky shores (Bertness et al. 2002) and 
salt marshes (Silliman et al. 2005). In particular, transplantation experiments that increase local densities of sea urchins in kelp beds can be used to rigorously test and define the feeding threshold ratio for destructive grazing, a key element of our model. In the Aleutian archipelago (North Pacific Ocean), where Strongylocentrotus polyacanthus also forms aggregations along the interface of kelp beds and barrens, Konar \& Estes (2003) found that experimentally increasing sea urchin density within kelp beds resulted in a marked decrease in the cover of kelp and other seaweeds and maintained barren patches in experimental plots where these algae initially were cleared. These types of experiments could be expanded to examine the effect on gap formation of different levels of the mean and variance of urchin density in kelp beds, as well as factors such as predators and wave action that affect the movement and foraging ability of sea urchins (Vadas et al. 1986, Konar \& Estes 2003, Lauzon-Guay \& Scheibling 2007b). Finally, experimental manipulation of kelp biomass or creation of gaps within kelp canopies could elucidate the role of disturbance, and its interaction with urchin grazing pressure, as a determinant of kelp bed stability. In the face of recent species invasions in the northwest Atlantic Ocean, which can profoundly alter the structure and dynamics of native macroalgal assemblages and associated sea urchin populations (Harris \& Tyrell 2001, Levin et al. 2002, Scheibling \& Gagnon 2006, 2009), the need for further theoretical and empirical research is urgent.

Acknowledgements.We acknowledge continuous long-term funding (27 yr for R.E.S.) by the Natural Sciences and Engineering Research Council of Canada (NSERC) in support of research on the rocky subtidal ecosystem in Nova Scotia. We thank D. A. Lyons for helpful discussions on our model and 4 anonymous reviewers for helpful comments on the manuscript.

\section{LITERATURE CITED}

Andersen T, Carstensen J, Hernandez-Garcia E, Duarte CM (2009) Ecological thresholds and regime shifts: approaches to identification. Trends Ecol Evol 24:49-57

Anstey ML, Rogers SM, Ott SR, Burrows M, Simpson SJ (2009) Serotonin mediates behavioral gregarization underlying swarm formation in desert locusts. Science 323:627-630

Balch T, Scheibling RE (2000) Temporal and spatial variability in settlement and recruitment of echinoderms in kelp beds and barrens in Nova Scotia. Mar Ecol Prog Ser 205: 139-154

Barkai A, McQuaid C (1988) Predator-prey role reversal in a marine benthic ecosystem. Science 242:62-64

Bernstein BB, Schroeter SC, Mann KH (1983) Sea urchin (Strongylocentrotus droebachiensis) aggregating behavior investigated by a subtidal multifactorial experiment. Can J Fish Aquat Sci 40:1975-1986

Bertness MD, Trussell GC, Ewanchuk PJ, Silliman BR (2002)
Do alternative stable community states exist in the Gulf of Maine rocky intertidal zone? Ecology 83:3434-3448

Bertness MD, Trussell GC, Ewanchuk PJ, Silliman BR (2004) Do alternate stable community states exist in the Gulf of Maine rocky intertidal zone? Reply. Ecology 85:1165-1167

Brady SM, Scheibling RE (2005) Repopulation of the shallow subtidal zone by green sea urchins (Strongylocentrotus droebachiensis) following mass mortality in Nova Scotia, Canada. J Mar Biol Assoc UK 85:1511-1517

Breen PA, Mann KH (1976a) Changing lobster abundance and destruction of kelp beds by sea urchins. Mar Biol 34: 137-142

Breen PA, Mann KH (1976b) Destructive grazing of kelp by sea urchins in Eastern Canada. J Fish Res Board Can 33: 1278-1283

Bruno JF, Sweatman H, Precht WF, Selig ER, Schutte VGW (2009) Assessing evidence of phase shifts from coral to macroalgal dominance on coral reefs. Ecology 90: 1478-1484

Chapman ARO (1981) Stability of sea urchin dominated barren grounds following destructive grazing of kelp in St. Margaret's Bay, Eastern Canada. Mar Biol 62:307-312

Chapman AS, Scheibling RE, Chapman ARO (2002) Species introductions and changes in marine vegetation of Atlantic Canada. In: Claudi R, Nantel P, Muckle-Jeffs E (eds) Alien invaders in Canada's waters, wetlands and forests. Natural Resources Canada, Canadian Forest Service Science Branch, Ottawa, ON, p 133-148

Chen Y, Hunter M (2003) Assessing the green sea urchin (Strongylocentrotus droebachiensis) stock in Maine, USA. Fish Res 60:527-537

> Dayton PK (1985) Ecology of kelp communities. Annu Rev Ecol Syst 16:215-245

deYoung B, Barange M, Beaugrand G, Harris R, Perry RI, Scheffer M, Werner F (2008) Regime shifts in marine ecosystems: detection, prediction and management. Trends Ecol Evol 23:402-409

> Dumont CP, Himmelman JH, Russell MP (2006) Daily movement of the sea urchin Strongylocentrotus droebachiensis in different subtidal habitats in eastern Canada. Mar Ecol Prog Ser 317:87-99

Elner RW, Vadas RL (1990) Inference in ecology: the sea urchin phenomenon in the northwestern Atlantic. Am Nat 136:108-125

> Estes JA, Duggins DO (1995) Sea otters and kelp forests in Alaska: generality and variation in a community ecological paradigm. Ecol Monogr 65:75-100

Evans M, Hastings N, Peacock JB (2000) Statistical distributions, 3rd edn. Wiley Interscience, New York

Folke C, Carpenter S, Walker B, Scheffer M, Elmquist T, Gunderson L, Holling CS (2004) Regime shifts, resilience, and biodiversity in ecosystem management. Annu Rev Ecol Syst 35:557-581

> Foreman RE (1977) Benthic community modification and recovery following intensive grazing by Strongylocentrotus droebachiensis. Helgol Wiss Meeresunters 30:468-484

Frank KT, Petrie B, Choi JS, Leggett WC (2005) Trophic cascades in a formerly cod-dominated ecosystem. Science 308:1621-1623

> Harris LG, Tyrell MC (2001) Changing community states in the Gulf of Maine: synergism between invaders, overfishing and climate change. Biol Invasions 3:9-21

Holling CS (1973) Resilience and stability of ecological systems. Annu Rev Ecol Syst 4:1-23

Hughes TP (1994) Catastrophes, phase shifts, and large-scale degradation of a Caribbean coral reef. Science 265: 1547-1551 
Johnson CR, Mann KH (1988) Diversity, patterns of adaptation, and stability of Nova Scotian kelp beds. Ecol Monogr 58:129-154

Kéfi S, Rietkerk M, Alados CL, Pueyo Y, Papanastasis VP, ElAich A, de Ruiter PC (2007) Spatial vegetation patterns and imminent desertification in Mediterranean arid ecosystems. Nature 449:213-217

Konar B, Estes JA (2003) The stability of boundary regions between kelp beds and deforested areas. Ecology 84: $174-185$

Lauzon-Guay JS, Scheibling RE (2007a) Behaviour of sea urchin Strongylocentrotus droebachiensis grazing fronts: food-mediated aggregation and density-dependent facilitation. Mar Ecol Prog Ser 329:191-204

Lauzon-Guay JS, Scheibling RE (2007b) Seasonal variation in movement, aggregation and destructive grazing of the green sea urchin (Strongylocentrotus droebachiensis) in relation to wave action and sea temperature. Mar Biol 151:2109-2118

Lauzon-Guay JS, Scheibling RE, Barbeau MA (2006) Movement patterns in the green sea urchin, Strongylocentrotus droebachiensis. J Mar Biol Assoc UK 86:167-174

Lauzon-Guay JS, Scheibling RE, Barbeau MA (2008) Formation and propagation of feeding fronts in benthic marine invertebrates: a modeling approach. Ecology 89: 3150-3162

> Lauzon-Guay JS, Scheibling RE, Barbeau MA (2009) Modelling phase shifts in a rocky subtidal ecosystem. Mar Ecol Prog Ser 375:25-39

Levin PS, Coyer JA, Petrik R, Good TP (2002) Communitywide effects of nonindigenous species on temperate rocky reefs. Ecology 83:3182-3193

Lewis S (1986) The role of herbivorous fishes in the organization of a Caribbean reef community. Ecol Monogr 56:183-200

Lyons DA, Scheibling RE (2007) Effect of dietary history and algal traits on feeding rate and food preference in the green sea urchin Strongylocentrotus droebachiensis. J Exp Mar Biol Ecol 349:194-204

Lyons DA, Scheibling RE (2008) Context-dependant survival of the invasive seaweed Codium fragile ssp. tomentosoides in kelp beds and urchin barren habitats off Nova Scotia. Aquat Biol 2:17-27

Lyons DA, Van Alstyne KL, Scheibling RE (2007) Anti-grazing activity and seasonal variation of dimethylsulfoniopropionate-associated compounds in the invasive alga Codium fragile ssp. tomentosoides. Mar Biol 153:179-188

Mann KH (1972) Ecological energetics of the seaweed zone in a marine bay on the Atlantic coast of Canada. I. Zonation and biomass of seaweeds. Mar Biol 12:1-10

Mann KH (1977) Destruction of kelp-beds by sea-urchins: a cyclical phenomenon or irreversible degradation? Helgol Wiss Meeresunters 30:455-467

Mann KH (1985) Invertebrate behaviour and the structure of marine benthic communities. In: Sibley RM, Smith RH (eds) Behavioural ecology. Blackwell Scientific, Oxford, p 227-246

May RM (1977) Thresholds and breakpoints in ecosystems with a multiplicity of stable states. Nature 269:471-477

McManus JW, Polsenberg JF (2004) Coral-algal phase shifts on coral reefs: ecological and environmental aspects. Prog Oceanogr 60:263-279

Meidel SK, Scheibling RE (2001) Variation in egg spawning among subpopulations of sea urchins Strongylocentrotus droebachiensis: a theoretical approach. Mar Ecol Prog Ser 213:97-110

Miller RJ (1985) Succession in sea urchin and seaweed abun- dance in Nova Scotia, Canada. Mar Biol 84:275-286

Mohn RK, Miller RJ (1987) A ration-based model of a seaweed-sea urchin community. Ecol Model 37:249-267

Moran PJ (1986) The Acanthaster phenomenon. Oceanogr Mar Biol Annu Rev 24:379-480

Mumby PJ (2009) Phase shifts and the stability of macroalgal communities on Caribbean coral reefs. Coral Reefs 28: 761-773

> Mumby PJ, Hastings A, Edwards HJ (2007) Thresholds and the resilience of Caribbean coral reefs. Nature 450:98-101

Pech RP, Sinclair ARE, Newsome AE, Catling PC (1992) Limits to predator regulation of rabbits in Australia: evidence from predator-removal experiments. Oecologia 89: 102-112

Peterson CH (1984) Does a rigorous criterion for environmental identity preclude the existence of multiple stable points? Am Nat 124:127-133

Petraitis PS, Dudgeon SR (2004a) Detection of alternative stable states in marine communities. J Exp Mar Biol Ecol 300:343-371

Petraitis PS, Dudgeon SR (2004b) Do alternate stable community states exist in the Gulf of Maine rocky intertidal zone? Comment. Ecology 85:1160-1165

Petraitis PS, Methratta ET, Rhile EC, Vidargas NA, Dudgeon SR (2009) Experimental confirmation of multiple community states in a marine ecosystem. Oecologia 161:139-148

Raymond BG, Scheibling RE (1987) Recruitment and growth of the sea urchin Strongylocentrotus droebachiensis (Muller) following mass mortalities off Nova Scotia, Canada. J Exp Mar Biol Ecol 108:31-54

Rietkerk M, Dekker SC, de Ruiter PC, van de Koppel J (2004) Self-organized patchiness and catastrophic shifts in ecosystems. Science 305:1926-1929

Robles CD, Desharnais RA, Garza C, Donahue MJ, Martinez CA (2009) Complex equilibria in the maintenance of boundaries: experiments with mussel beds. Ecology 90: 985-995

Russell MP, Ebert TA, Petraitis PS (1998) Field estimates of growth and mortality of the green sea urchin, Strongylocentrotus droebachiensis. Ophelia 48:137-153

> Saunders M, Metaxas A (2008) High recruitment of the introduced bryozoan Membranipora membranacea is associated with kelp bed defoliation in Nova Scotia, Canada. Mar Ecol Prog Ser 369:139-151

> Scheffer M, Carpenter S, Foley JA, Folke C, Walker B (2001) Catastrophic shifts in ecosystems. Nature 413:591-596

> Scheffer M, Carpenter S, De Young B (2005) Cascading effects of overfishing marine systems. Trends Ecol Evol 20:579-581

> Scheibling RE (1984) Echinoids, epizootics and ecological stability in the rocky subtidal off Nova Scotia, Canada. Helgol Wiss Meeresunters 37:233-242

Scheibling RE (1986) Increased macroalgal abundance following mass mortalities of sea urchins (Strongylocentrotus droebachiensis) along the Atlantic coast of Nova Scotia. Oecologia 68:186-198

Scheibling RE (1996) The role of predation in regulating sea urchin populations in eastern Canada. Oceanol Acta 19:421-430

Scheibling RE, Anthony SX (2001) Feeding, growth and reproduction of sea urchins (Strongylocentrotus droebachiensis) on single and mixed diets of kelp (Laminaria spp.) and the invasive alga Codium fragile ssp. tomentosoides. Mar Biol 139:139-146

Scheibling RE, Gagnon P (2006) Competitive interactions between the invasive green alga Codium fragile ssp. tomentosoides and native canopy-forming seaweeds in 
Nova Scotia (Canada). Mar Ecol Prog Ser 325:1-14

Scheibling RE, Gagnon P (2009) Temperature-mediated outbreak dynamics of the invasive bryozoan Membranipora membranacea in Nova Scotian kelp beds. Mar Ecol Prog Ser 390:1-13

Scheibling RE, Hamm J (1991) Interactions between sea urchins (Strongylocentrotus droebachiensis) and their predators in field and laboratory experiments. Mar Biol 110:105-116

Scheibling RE, Hatcher BG (2006) The ecology of Strongylocentrotus droebachiensis. In: Lawrence JM (ed) Edible sea urchins: biology and ecology, 2nd edn. Elsevier Science, Amsterdam, p 353-392

Scheibling RE, Robinson MC (2008) Settlement behaviour and early post-settlement predation of the sea urchin Strongylocentrotus droebachiensis. J Exp Mar Biol Ecol 365:59-66

Scheibling RE, Stephenson RL (1984) Mass mortality of Strongylocentrotus droebachiensis (Echinodermata: Echinoidea) off Nova Scotia, Canada. Mar Biol 78:153-164

Scheibling RE, Hennigar AW, Balch T (1999) Destructive grazing, epiphytism, and disease: the dynamics of sea urchin - kelp interactions in Nova Scotia. Can J Fish Aquat Sci 56:2300-2314

Schröder A, Lennart P, De Roos AM (2005) Direct experimental evidence for alternative stable states: a review. Oikos 110:3-19

Siegel DA, Mitarai S, Costello CJ, Gaines SD, Kendall BE, Warner RR, Winters KB (2008) The stochastic nature of larval connectivity among nearshore marine populations. Proc Natl Acad Sci USA 105:8974-8979

Silliman BR, van de Koppel J, Bertness MD, Stanton L, Mendelsohn I (2005) Drought, snails, and large-scale dieoff of southern U.S. salt marshes. Science 310:1803-1806

Simenstad CA, Estes JA, Kenyon KW (1978) Aleuts, sea otters, and alternate stable-state communities. Science 200:403-411

Sivertsen K, Hopkins CCE (1995) Demography of the echi-

Editorial responsibility: Matthias Seaman,

Oldendorf/Luhe, Germany noid Strongylocentrotus droebachiensis related to biotope in northern Norway. In: Skjoldal HR, Hopkins C, Erikstad KE, Leinaas HP (eds) Ecology of fjords and coastal waters. Elsevier Science, Amsterdam, p 549-571

Solé RV, Bascompte J (2006) Spatial self-organization: from pattern to process. In: Solé RV, Bascompte J (eds) Selforganization in complex ecosystems. Princeton University Press, Princeton, NJ, p 65-125

Steele JH (2004) Regime shifts in the ocean: reconciling observations and theory. Prog Oceanogr 60:135-141

Steneck RS, Graham MH, Bourque BJ, Corbett D, Erlandson JM, Estes J, Tegner MJ (2002) Kelp forest ecosystems: biodiversity, stability, resilience and future. Environ Conserv 29:436-459

Sumi CBT, Scheibling RE (2005) Role of grazing by sea urchins Strongylocentrotus droebachiensis in regulating the invasive alga Codium fragile ssp. tomentosoides in Nova Scotia. Mar Ecol Prog Ser 292:203-212

Sutherland JP (1974) Multiple stable points in natural communities. Am Nat 108:859-873

Sutherland JP (1990) Perturbations, resistance, and alternative views of the existence of multiple stable points in nature. Am Nat 136:270-275

Vadas RL, Elner RW, Garwood PE, Babb IG (1986) Experimental evaluation of aggregation behavior in the sea urchin Strongylocentrotus droebachiensis. Mar Biol 90:433-448

van de Koppel J, Herman PMJ, Thoolen P, Heip CHR (2001) Do alternate stable states occur in natural ecosystems? Evidence from a tidal flat. Ecology 82:3449-3461

van de Koppel J, Gascoigne JC, Theraulaz G, Rietkerk M, Mooij WM, Herman PMJ (2008) Experimental evidence for spatial self-organization and its emergent effects in mussel bed ecosystems. Science 322:739-742

Wharton WG, Mann KH (1981) Relationship between destructive grazing by the sea urchin, Strongylocentrotus droebachiensis, and the abundance of American lobster, Homarus americanus, on the Atlantic coast of Nova Scotia. Can J Fish Aquat Sci 38:1339-1349

Submitted: July 8, 2009; Accepted: January 13, 2010

Proofs received from author(s): March 4, 2010 